\title{
Effects of Point-of-care Ultrasonography on the Diagnostic Process of Patients Admitted to the Emergency Department with Chest Pain: A Randomised Controlled Trial
}

\author{
Necip Gokhan Guner ${ }^{1}$, Yusuf Yurumez ${ }^{1}$, Murat Yucel ${ }^{1}$, Mehmet Alacam ${ }^{1}$, Seda Turkmen Guner ${ }^{2}$ and Bilge Ercan ${ }^{1}$ \\ ${ }^{1}$ Department of Emergency Medicine, Sakarya University Training and Research Hospital, Turkey \\ ${ }^{2}$ Department of Family Medicine, Sakarya University Training and Research Hospital, Turkey
}

\begin{abstract}
Objective: To evaluate the effect of point of care ultrasonography (POCUS) performed for heart, lung, aorta, hepatobiliary and deep veins on the diagnosis, length of stay (LOS) in emergency department (ED) and cost in patients admitted to the ED with chest pain.

Study Design: Prospective randomised controlled, parallel-group trial.

Place and Duration of Study: Sakarya University Training and Research Hospital, Sakarya Turkey, from September 2018 to March 2019.

Methodology: Patients ( $\geq 18$ years) with chest pain were randomly assigned at a 1:1 ratio to a standard diagnostic strategy (control group) or to standard diagnostic strategy supplemented with POCUS (POCUS group). Data obtained from the study were analysed using IBM SPSS Statistics 21.

Results: Two hundred and eight patients were randomly assigned to the control $(n=104)$ and POCUS groups $(n=104)$, respectively. The mean age was $50.42 \pm 16.15$, and $54 \%$ were men. The most common comorbidity was hypertension (43\%). Non-ST elevation myocardial infarction and musculoskeletal pain were the most common presumptive diagnoses. POCUS significantly reduced the LOS in ED. Detection of pathology in the POCUS increased the rate of hospitalisation. In addition, POCUS significantly shortened the LOS in the ED in patients who were discharged. The median LOS in the ED for the POCUS group was 133 min (91-279), which was significantly shorter than that of the control group at $215 \mathrm{~min}(118-372)(p=0.006)$. Although the average costs were also reduced, the difference was not statistically significant $(p=0.269)$.

Conclusion: POCUS is a repeatable, practical imaging method which does not require radiation, reduces LOS in the ED statistically significant. However, further studies are needed to determine its usefulness in the ED.
\end{abstract}

Key Words: Chest pain, Cost, Emergency medicine, Length of stay, Point of care ultrasound.

How to cite this article: Guner NG, Yurumez Y, Yucel M, Alacam M, Guner ST, Ercan B. Effects of Point-of-care Ultrasonography on the Diagnostic Process of Patients Admitted to the Emergency Department with Chest Pain: A Randomised Controlled Trial. J Coll Physicians Surg Pak 2020; 30(12):1262-1268.

\section{INTRODUCTION}

Chest pain (CP) is one of the most common reasons for visiting the emergency department (ED). It is also the first symptom of many diseases. ${ }^{1,2}$ In the United States of America (USA), approximately 6 million patients with CP visited the ED annually, which costs approximately $\$ 8$ billion. This amount constitutes approximately $9 \%$ of all visits to the ED. ${ }^{3}$

Correspondence to: Dr. Necip Gokhan Guner, Department of Emergency Medicine, Sakarya University Training and Research Hospital, Turkey

E-mail: gunernecipgokhan@gmail.com

Received: September 15, 2020; Revised: November 05, 2020; Accepted: November 05, 2020

DOI: https://doi.org/10.29271/jcpsp.2020.12.1262

$\mathrm{CP}$ is often caused by life threatening diseases, such as acute coronary syndrome, aortic dissection, pneumothorax, pulmonary embolism, pericardial tamponade, and esophageal rupture. ${ }^{4}$ Important difficulties encountered in the evaluation of patients with $C P$ in the ED include the presence of comorbidities that may cause this symptom and the need to make a differential diagnosis rapidly, but this is time-consuming and not always possible. ${ }^{5}$ Therefore, history and physical examination are focused on the exclusion or confirmation of serious pathology in patients visiting the ED. However, these are often insufficient, and electrocardiogram (ECG), chest X-ray, and cardiac biomarkers are often used. ${ }^{6}$

Another diagnostic method used in the differential diagnosis of $\mathrm{CP}$ is point-of-care ultrasonography (POCUS), which has become an integral method of emergency care in the USA in the last 20 years. In addition, POCUS stands out worldwide with its advanced diagnostic and therapeutic capabilities. ${ }^{7}$ Results of several studies in ED have shown that sonographic examina- 
tions have excellent diagnostic accuracy for diseases most commonly encountered in patients. ${ }^{8}$ These diseases most often involve the heart, lungs, or deep veins of the legs, all of which can be directly visualized with sonography. ${ }^{9}$ The idea of using POCUS as a stethoscope is rapidly becoming integrated into clinical practice and medical education. ${ }^{10}$ Despite being a rapidly evolving diagnostic test, knowledge is needed about whether POCUS actually increases the proportion of patients who are correctly diagnosed and treated in the ED. ${ }^{8}$ Besides improving the health care of individuals, improved diagnostic assessment with POCUS might also have a positive effect at a societal level (by reducing health-care costs and morbidity and mortality rates) because respiratory and cardiac diseases are all major publichealth problems. ${ }^{11}$

It was hypothesised that performing POCUS to patients presenting to the ED with CP will positively contribute to the diagnostic process, shorten the length of stay (LOS) in the ED, and reduce the average costs. The objective of this study was to evaluate the effect of POCUS performed for heart, lung, aorta, hepatobiliary and deep veins on the diagnosis, LOS in ED and costs in patients admitted to the ED with chest pain.

\section{METHODOLOGY}

This prospective, parallel-group, randomised controlled trial, with a superiority design, was conducted at the medical ED at Sakarya University Training and Research Hospital, Sakarya, Turkey. Informed consent was obtained from all individual participants included in the study. Also all procedures performed in studies involving human participants were in accordance with the ethical standards of the institutional and/or national research committee and with the 1964 Helsinki Declaration and its later amendments or comparable ethical standards. The study was approved by the Sakarya University Clinical Research Ethics Committee (Decision No. 05 of 12.09.2018). The study is registered with ClinicalTrials.gov, No. NCT04429698.

Patients admitted to the ED were included in this study, if they had CP. Exclusion criteria were permanent mental disability, age $<18$ years, chest trauma in the last 24 hours, pregnancy, need for urgent angiography with ST elevation myocardial infarction, referral from an external center to the ED, and incomplete patient information.

The patients were randomly assigned to the POCUS or control groups. The principal investigator randomised the allocation of patients form to the groups at a 1:1 ratio by using a random number generator before the study began. When the patients admitted, it was determined in advance which numbered form was included in which group. The POCUS operator was present at alternating shifts in the ED, this situation caused inclusion of patients at different times of the day or night, and different days of the week.

Primary clinical evaluation was performed in all patients admitted to the ED. Primary clinical evaluation is defined as the evaluation of the patient by the primary physician at the time of admission to the ED.

After the primary clinical evaluation, demographic data of all patients, characteristics of $\mathrm{CP}$, location, extent, duration, vital parameters, and preliminary diagnosis of the primary physician were recorded in the study form. There was no suggestion or referral to the primary physician regarding the diagnostic approach and treatment processes.

The physician was not limited to request for complete blood count, cardiac markers, and biochemical analyses, ECG, and other imaging tests (chest X-ray, computed tomography, ultrasonography, and echocardiography), which are among the standard tests in the ED, and results can be obtained in approximately 2 hours.

Atthis stage, the patients were divided into two groups:

POCUS group underwent POCUS after primary clinical evaluation, in the first hour after the patients' primary clinical evaluations to evaluate the predetermined parameters in the study form for the heart, lungs, hepatobiliary, aorta, and deep veins. In the Control group; all processes and results were followed without any intervention for patients in this group, and the results were recorded in the study form.

All examinations were performed according to the American College of Emergency Physician imaging criteria by the same POCUS operator, who didn't provide primary patient care, qualified in POCUS (>250 examinations performed with focus assessed transthoracic echocardiography, $>250$ with focused lung ultrasonography, $>250$ hepatobiliary ultrasonography, $>250$ aortic ultrasonography and >500 with limited compression ultrasonography). Xario 100 (Toshiba, Japan) ultrasonography system was used.

After POCUS, the findings were presented to the physician in the ED who performed primary assessment, and the preliminary diagnoses, diagnostic tests, and treatment were reassessed. Without any intervention to the processes after this stage, the results, including all the processes and costs (the final amount), were recorded in the study form.

After these processes, the summaries of hospitalised patients and ED patient examination forms, laboratory, and imaging tests of the discharged patients were evaluated and recorded by a supervisor emergency medical specialist who masked POCUS findings and the patient's primary physician.

The primary endpoint was to determine the effect of POCUS on the ED LOS. The secondary endpoints were to determine the effect of POCUS on the average cost of patients, the rate of change in the preliminary diagnosis of the physician, hospitalisation and discharge rates.

For both groups, categorical endpoints were summarised as the numbers and percentages of patients with corresponding $95 \%$ confidence intervals (Cls); continuous end points were presented as the number of patients, mean, standard deviation, median, and interquartilerange. 
Table I: Demographic and clinical findings of patients in POCUS and control groups.

\begin{tabular}{|c|c|c|c|}
\hline & $\begin{array}{c}\text { POCUS group } \\
(n=104)\end{array}$ & $\begin{array}{c}\text { Control group } \\
(n=104)\end{array}$ & $\begin{array}{l}\text { All patients } \\
(n=208)\end{array}$ \\
\hline Age (years; mean \pm SD) & $50.28 \pm 16.13$ & $50.56 \pm 16.26$ & $50.42 \pm 16.15$ \\
\hline $\begin{array}{l}\text { Gender } \\
\text { Male } \\
\text { Female }\end{array}$ & $\begin{array}{l}55(53 \%) \\
49(47 \%)\end{array}$ & $\begin{array}{l}57(55 \%) \\
47(45 \%)\end{array}$ & $\begin{array}{c}112(54 \%) \\
96(46 \%)\end{array}$ \\
\hline $\begin{array}{l}\text { Medical history } \\
\text { Diabetes mellitus } \\
\text { Coronary artery disease } \\
\text { Hyperlipidemia } \\
\text { Heart failure } \\
\text { Arterial hypertension } \\
\text { Stroke } \\
\text { Chronic kidney disease } \\
\text { Psychiatric disorders } \\
\text { Chronic obstructive pulmonary disease } \\
\text { Asthma } \\
\text { Others }\end{array}$ & $\begin{array}{c}25(24 \%) \\
19(18 \%) \\
6(6 \%) \\
4(4 \%) \\
44(42 \%) \\
1(1 \%) \\
3(3 \%) \\
8(8 \%) \\
4(4 \%) \\
3(3 \%) \\
19(18 \%)\end{array}$ & $\begin{array}{c}23(22 \%) \\
16(15 \%) \\
7(7 \%) \\
5(5 \%) \\
46(44 \%) \\
3(3 \%) \\
5(5 \%) \\
6(6 \%) \\
6(6 \%) \\
3(3 \%) \\
12(12)\end{array}$ & $\begin{array}{c}48(23 \%) \\
35(17 \%) \\
13(6 \%) \\
9(4 \%) \\
90(43 \%) \\
4(2 \%) \\
8(4 \%) \\
14(7 \%) \\
10(5 \%) \\
6(3 \%) \\
31(15 \%)\end{array}$ \\
\hline $\begin{array}{l}\text { Vital signs at admission } \\
\text { Respiratory rate (breaths per min) } \\
\text { Saturation }(\%) \\
\text { Systolic blood pressure }(\mathrm{mm} \mathrm{Hg}) \\
\text { Diastolic blood pressure }(\mathrm{mm} \mathrm{Hg}) \\
\text { Heart rate (beats per min) } \\
\text { Temperature }\left({ }^{\circ} \mathrm{C}\right)\end{array}$ & $\begin{array}{c}12(11-12) \\
98(97-99) \\
120(110-140) \\
70(70-80) \\
85(77-88) \\
36.7(36.5-36.9)\end{array}$ & $\begin{array}{c}12(11-12) \\
98(96-98) \\
120(110-140) \\
75(70-80) \\
86(77-94) \\
36.7(36.5-36.9)\end{array}$ & $\begin{array}{c}12(11-12) \\
98(97-99) \\
120(110-140) \\
75(70-80) \\
85(77-92) \\
36.7(36.5-36.9)\end{array}$ \\
\hline $\begin{array}{l}\text { Patient reported symptoms } \\
\text { Dyspnea } \\
\text { Tachypnea } \\
\text { Sweating } \\
\text { Orthopnea } \\
\text { Palpitation } \\
\text { Paroxysmal nocturnal dyspnoea } \\
\text { Fever } \\
\text { Increase in sputum quantity or purulence } \\
\text { Oedema of both legs } \\
\text { Nausea } \\
\text { Dyspepsia } \\
\text { The fear of death } \\
\text { Cough } \\
\text { Dysuria }\end{array}$ & $\begin{array}{c}25(24 \%) \\
9(9 \%) \\
7(7 \%) \\
6(6 \%) \\
10(10 \%) \\
4(4 \%) \\
4(4 \%) \\
4(4 \%) \\
7(7 \%) \\
7(7 \%) \\
47(45 \%) \\
32(31 \%) \\
28(27 \%) \\
3(3 \%)\end{array}$ & $\begin{aligned} & 29(28 \%) \\
& 11(11 \%) \\
& 15(14 \%) \\
& 5(5 \%) \\
& 13(13 \%) \\
& 4(4 \%) \\
& 2(2 \%) \\
& 2(2 \%) \\
& 9(9 \%) \\
& 12(12 \%) \\
& 55(53 \%) \\
& 22(21 \%) \\
& 22(21 \%) \\
& 1(1 \%)\end{aligned}$ & $\begin{array}{c}54(26 \%) \\
20(10 \%) \\
22(11 \%) \\
11(5 \%) \\
23(11 \%) \\
8(4 \%) \\
6(3 \%) \\
6(3 \%) \\
16(8 \%) \\
19(9 \%) \\
102(49 \%) \\
54(26 \%) \\
50(24 \%) \\
4(2 \%)\end{array}$ \\
\hline $\begin{array}{l}\text { Duration of chest pain } \\
\text { Acute } \\
\text { Non-acute }\end{array}$ & $\begin{array}{l}87(84 \%) \\
17(16 \%)\end{array}$ & $\begin{array}{l}90(87 \%) \\
14(13 \%)\end{array}$ & $\begin{array}{c}177(85 \%) \\
31(15 \%)\end{array}$ \\
\hline $\begin{array}{l}\text { Locatıon of chest paın } \\
\text { Retrosternal } \\
\text { Left side of chest } \\
\text { Whole chest } \\
\text { Epigastric } \\
\text { Back }\end{array}$ & $\begin{array}{c}16(15 \%) \\
54(52 \%) \\
32(31 \%) \\
3(3 \%) \\
4(4 \%)\end{array}$ & $\begin{array}{c}18(17 \%) \\
58(56 \%) \\
26(25 \%) \\
3(3 \%) \\
4(4 \%)\end{array}$ & $\begin{array}{c}34(16 \%) \\
112(54 \%) \\
58(28 \%) \\
6(3 \%) \\
8(4 \%)\end{array}$ \\
\hline $\begin{array}{l}\text { Radiation of chest pain } \\
\text { Right shoulder and arm } \\
\text { Left shoulder and arm } \\
\text { Neck } \\
\text { Epigastric } \\
\text { Back } \\
\text { Abdomen } \\
\text { No radiation }\end{array}$ & $\begin{array}{c}-(-) \\
11(11 \%) \\
-(-) \\
21(20 \%) \\
24(23 \%) \\
1(1 \%) \\
51(49 \%)\end{array}$ & $\begin{aligned} 1 & (1 \%) \\
10 & (10 \%) \\
2 & (2 \%) \\
24 & (23 \%) \\
30 & (29 \%) \\
1 & (1 \%) \\
45 & (43 \%)\end{aligned}$ & $\begin{aligned} 1 & (0 \%) \\
21 & (10 \%) \\
2 & (1 \%) \\
44 & (21 \%) \\
54 & (26 \%) \\
2 & (1 \%) \\
96 & (46 \%)\end{aligned}$ \\
\hline $\begin{array}{l}\text { Character of chest pain } \\
\text { Crushing, tightness, squeezing, pressure } \\
\text { Pleuritic } \\
\text { Ripping, tearing } \\
\text { Sudden, sharp } \\
\text { After forceful vomiting } \\
\text { Positional } \\
\text { Increasing with suppression } \\
\text { Increasing with efort } \\
\text { Unrelated to efort } \\
\text { Burning sensation in the chest }\end{array}$ & $\begin{array}{c}25(24 \%) \\
59(57 \%) \\
1(1 \%) \\
17(16 \%) \\
1(1 \%) \\
37(36 \%) \\
12(12 \%) \\
20(19 \%) \\
64(62 \%) \\
4(4 \%)\end{array}$ & $\begin{array}{c}24(23 \%) \\
57(55 \%) \\
1(1 \%) \\
13(13 \%) \\
-(-) \\
45(43 \%) \\
9(9 \%) \\
20(19 \%) \\
72(69 \%) \\
6(6 \%)\end{array}$ & $\begin{array}{c}49(24 \%) \\
116(56 \%) \\
2(1 \%) \\
30(14 \%) \\
1(0 \%) \\
82(39 \%) \\
21(10 \%) \\
40(19 \%) \\
136(65 \%) \\
10(5 \%)\end{array}$ \\
\hline $\begin{array}{l}\text { Imagining methods } \\
\text { Electrocardogram } \\
\text { X-ray } \\
\text { Computed Tomography }\end{array}$ & $\begin{array}{l}100(96 \%) \\
83(80 \%) \\
13(13 \%)\end{array}$ & $\begin{array}{l}102(98 \%) \\
92(88 \%) \\
22(21 \%)\end{array}$ & $\begin{array}{c}202(97 \%) \\
175(84 \%) \\
35(17 \%)\end{array}$ \\
\hline $\begin{array}{l}\text { Hospitalisation of patient } \\
\text { Discharged } \\
\text { Hospitalize }\end{array}$ & $\begin{array}{l}70(67 \%) \\
34(33 \%)\end{array}$ & $\begin{array}{l}74(71 \%) \\
30(29 \%)\end{array}$ & $\begin{array}{c}143(69 \%) \\
64(31 \%)\end{array}$ \\
\hline POCUS group's ultrasound findings & & Present & Absent \\
\hline
\end{tabular}




\begin{tabular}{|c|c|c|}
\hline $\begin{array}{l}\text { Cardiac ultrasound } \\
\text { Parasternal long axis } \\
\text { Pericardial effusion } \\
\text { Dissection flap } \\
\text { Pericardium thickening } \\
\text { Valve Vegetation } \\
\text { Aortic root }>5 \mathrm{~cm} \\
\text { Parasternal short axis } \\
\text { Myocardial regional wall motion abnormality } \\
\text { Apical four chamber } \\
\text { Right ventricle enlargement } \\
\text { Mcconnell's sign } \\
\text { Myocardial regional wall motion abnormality } \\
\text { Systolic right atrium collapse } \\
\text { Diastolic right ventricular collapse }\end{array}$ & $\begin{array}{c}4(4 \%) \\
0(0 \%) \\
0(0 \%) \\
0(0 \%) \\
0(0 \%) \\
20(19 \%) \\
0(0 \%) \\
0(0 \%) \\
14(13 \%) \\
0(0 \%) \\
0(0 \%)\end{array}$ & $\begin{array}{c}100(96 \%) \\
104(100 \%) \\
104(100 \%) \\
104(100 \%) \\
104(100 \%) \\
84(81 \%) \\
104(100 \%) \\
104(100 \%) \\
90(87 \%) \\
104(100 \%) \\
104(100 \%)\end{array}$ \\
\hline $\begin{array}{l}\text { Lung ultrasound } \\
\text { B lines } \\
\text { Pleural effusion } \\
\text { Pneumothorax }\end{array}$ & $\begin{aligned} & 12(12 \%) \\
& 7(7 \%) \\
& 4(4 \%)\end{aligned}$ & $\begin{array}{c}92(88 \%) \\
97(93 \%) \\
100(96 \%)\end{array}$ \\
\hline $\begin{array}{l}\text { Hepatobiliary ultrasound } \\
\text { Increase in gallbladder wall thickness } \\
\text { Stone/mud in the gallbladder } \\
\text { Sonographic murphy's sign } \\
\text { Enlargement of common bile duct }\end{array}$ & $\begin{array}{l}0(0 \%) \\
8(8 \%) \\
0(0 \%) \\
0(0 \%)\end{array}$ & $\begin{aligned} & 104(100 \%) \\
& 96(92 \%) \\
& 104(100 \%) \\
& 104(100 \%)\end{aligned}$ \\
\hline $\begin{array}{l}\text { Abdominal aortic ultrasound } \\
\text { Dissection flap } \\
\text { Suprarenal aortic diameter }>3 \mathrm{~cm} \\
\text { Infrarenal aortic diameter }>3 \mathrm{~cm}\end{array}$ & $\begin{array}{l}0(0 \%) \\
0(0 \%) \\
0(0 \%)\end{array}$ & $\begin{array}{l}104(100 \%) \\
104(100 \%) \\
104(100 \%)\end{array}$ \\
\hline $\begin{array}{l}\text { Ultrasound for deep vein thrombosis } \\
\text { Thrombus in right lower extremity } \\
\text { Thrombus in Left Lower Extremity }\end{array}$ & $\begin{array}{l}0(0 \%) \\
0(0 \%)\end{array}$ & $\begin{array}{l}104(100 \%) \\
104(100 \%)\end{array}$ \\
\hline
\end{tabular}

Table II: Effects of POCUS on the differential diagnoses.

\begin{tabular}{|c|c|c|c|}
\hline $\begin{array}{l}\text { Presumptive } \\
\text { differential diagnosis (ddx) }\end{array}$ & $\begin{array}{c}\text { Pre-Pocus } \\
\text { differential diagnosis } \\
(n=104)\end{array}$ & $\begin{array}{c}\text { Post-Pocus } \\
\text { differential diagnosis } \\
(n=104)\end{array}$ & p-value* \\
\hline Non-ST elevation myocardial infarction & 102 & 85 & 0.000 \\
\hline Pneumothorax & 28 & 5 & 0.000 \\
\hline Pneumonia & 32 & 10 & 0.000 \\
\hline Musculoskeletal pain & 88 & 83 & 0.103 \\
\hline Pleurisy & 7 & 6 & 1.000 \\
\hline Aort dissection & 7 & 3 & 0.289 \\
\hline Pericarditis & 16 & 3 & 0.002 \\
\hline Pulmonary embolism & 9 & 0 & 0.004 \\
\hline Gastroesophageal reflux disesase & 16 & 4 & 0.000 \\
\hline Cholecystitis & 4 & 1 & 0.375 \\
\hline Total number of DDX per patient (median (25p-75p)) & $3(2-4)$ & $2(1,25-2)$ & 0.000 \\
\hline
\end{tabular}

The rule of three was used to calculate $95 \% \mathrm{Cl}$ in categories with no events. The Student $t$ test, Mann-Whitney U-test or Wilcoxon test were used for comparison of continuous endpoints, and the $\chi^{2}$ and McNemar tests were used for comparison of endpoints expressed as categorically. All tests were performed with a two-sided significance of $5 \%$. For each endpoint, the absolute and relative effects and their corresponding $95 \% \mathrm{Cls}$ were calculated as recommended by Altman et al. ${ }^{12}$ All analyses were performed using IBM SPSS Statistics 21.

\section{RESULTS}

The demographic and clinical findings of the 208 patients included in the study are shown in Table I.

In the POCUS group, 69 pathological findings in 32 patients were detected, such as pericardial effusion, myocardial regional wall motion abnormality, gallbladder stone/sludge, B lines, pleural effusions, pneumothorax, and aortic aneurysm. The most common of these was a myocardial regional wall motion abnormality, whereas the least common was pericardial effusion and pneumothorax (Table I).

On an average, the primary physician initially considered four differential diagnoses based on history and physical examination, and an average of two of these diagnoses were conducive to sonographic evaluation. After ultrasonography, the mean number of differential diagnoses decreased from three to two $(p<0.001)$. After POCUS evaluation, a statistically significant decrease was found in most pre-diagnoses as nonST elevation myocardial infarction (NSTEMI), pneumothorax, pneumonia, pericarditis, pulmonary embolism and gastroesophageal reflux disease $(p<0,001 ; p<0,001 ; p<0,001$; $p=0,002 ; p=0,004 ; p<0,001$, respectively, Table II).

NSTEMI and musculoskeletal pain were the most common presumed diagnoses in patients admitted to the ED. 
Performing POCUS on patients presenting with non-acute CP was found to significantly decrease the LOS in the ED $(p=0.006)$; in terms of pain characteristics, we found that patients in the POCUS group who described pleuritic pain significantly wait less than the control group $(p=0.003)$.

The use of ECG and chest X-ray and imaging methods together with POCUS in patients presenting to the ED with $C P$ has reduced the LOS in the ED.

When the last diagnoses were evaluated, POCUS significantly reduced the LOS in the ED in patients with the final diagnosis of musculoskeletal pain. After the patients were examined and subsequently discharged, the LOS in the ED in the POCUS group was shorter than that in the control group. When all patients were considered, we found that performing POCUS significantly shortened the LOS in the ED. In addition, performing POCUS did not reduce the average costs (Table III).

When the POCUS group was examined, the LOS in the ED was prolonged in patients with pathology detected during ultrasonography, and the average costs were higher (respectively, $212 \mathrm{~min}(113-391) v s .123 \mathrm{~min}(85-257) \mathrm{p}=0.012 ; 30.9 \pm 18.4$ vs. 22.6 $\pm 13.1 p=0.026)$. In addition, the presence of pathology on ultrasonography significantly increased hospitalisation rates (discharged $=7$ patients $21.9 \%$ vs. hospitalized $=25$ patients $78.1 \%, \mathrm{p}<0.001$ ).

\section{DISCUSSION}

$\mathrm{CP}$ is among the most common causes of referral to the ED and is among the most important symptoms of cardiovascular diseases, which ranks first among the most common causes of deaths worldwide. CP is caused by many cardiac and non-cardiac causes, and that serious increases in mortality and morbidity occur when the approach is not performed correctly and in time, increase the importance of diagnostic approaches. In this context, the effectiveness of POCUS was investigated to ensure that patients with CP visiting the ED were diagnosed and treated early, as well as to shorten the LOS in the ED and reduce the diagnostic process.

Studies by Lamsam et al. and Buhumaid et al. investigated the diagnostic efficacy of POCUS in patients presenting to the ED with CP and respiratory symptoms. ${ }^{13,14}$ However, to the best of authors' knowledge, no randomized controlled clinical trial has investigated the effect of POCUS on the LOS in ED and costs in patients with $\mathrm{CP}$.

The demographic characteristics of the patients in this study were consistent with those of previous studies in the literature related to CP. For example, in the study by Lamsam et al., the mean age was 59 years, and in our study, it was 50.42 years. ${ }^{14}$ In the study by Buhumaid et al., $55 \%$ of the patients with CP who visited the ED were men. Similarly, this rate was $57.6 \%$ and $64 \%$ in the study by Lamsam et al. and Carubbi et al., respectively. In our study, similar to the literature, $54 \%$ of men with CP visited the ED more frequently than women with $\mathrm{CP} .{ }^{13-15}$

POCUS, a diagnostic tool recommended in the differential diagnosis approach, is very useful in making quick and accurate decisions, revealing pathologies and shaping pre-diagnoses. Using POCUS, pericardial effusion, myocardial contraction defect, enlarged heart chambers, $B$ lines in the lung, pleural effusion, pneumothorax, aortic aneurysm, aortic dissection, deep vein thrombosis, pathologies of the gallbladder, and many organ pathologies can be detected. ${ }^{7}$ Considering the studies conducted to investigate pathologies, the detection rate was $20 \%$ and $30 \%$ in the study by Yates et al. and Buhumaid et al., respectively. ${ }^{13,16}$ The most frequent pathological finding is decreased ejection fraction of the heart due to myocardial wall motion defect, and the most common irregular pleural line and $B$ lines in terms of lung. The detection rate of pathological findings in our study was $34 \%$. The most common pathological findings were myocardial wall motion defect and diffuse $B$ lines in the lung. These results are also consistent with the literature. $^{13,16}$

It is stated in ACEP's ultrasonography guide that POCUS can have a positive effect on the diagnosis and treatment process in patients with $\mathrm{CP}$ admitted to the ED. ${ }^{7}$ In this study, after performing ultrasonography, the median number of differential diagnoses decreased from three (2-4) to two (1.25-2.00; $p<0.001)$. Following POCUS evaluation, a statistically significant decrease was found in all sonographically identifiable diagnoses. These results are consistent with previous studies in which POCUS was found to be a feasible and accurate diagnostic tool in patients presenting with $C P{ }^{13,17}$ In addition, the detection of pathology in the POCUS has increased the rate of hospitalization similar to the study by Elikashvili et al. ${ }^{18}$

In our study, the median value of the LOS in the ED of the POCUS and control groups was 133 (91-279) and 215 (118-372) minutes, respectively, which was statistically significant $(p=0,006)$. A study investigating the effect of POCUS on the LOS in the ED in patients with CP admitted to the ED has not been found in the literature, but the studies by Lin et al. investigating patients with soft tissue infection, by Park et al. for patients with renal colic, by Elikashvili et al. for patients with suspected appendicitis, and by Wilson et al. achieved the same result in patients admitted to the ED due to pelvic pain and vaginal bleeding. ${ }^{18-21}$

Table III. Effects of POCUS on the LOS and average costs.

\begin{tabular}{|c|c|c|c|c|c|c|}
\hline & \begin{tabular}{|c|} 
Pocus group \\
$*$ los $(\min )$ \\
median $(25 p-75 p)$ \\
\end{tabular} & $\begin{array}{c}\text { Control group } \\
* \text { los }(\min ) \\
\text { median }(25 p-75 p)\end{array}$ & p-value** & $\begin{array}{l}\text { Pocus group } \\
\text { average costs } \\
\text { (mean } \pm \text { sd ; \$) }\end{array}$ & $\begin{array}{l}\text { Control group } \\
\text { average costs } \\
\text { (mean } \pm \text { sd ; \$) }\end{array}$ & p-value** \\
\hline
\end{tabular}




\begin{tabular}{|c|c|c|c|c|c|c|}
\hline $\begin{array}{l}\text { Duration of chest pain } \\
\text { Acute } \\
\text { Non-acute }\end{array}$ & $\begin{array}{l}160(98-290) \\
130(89-270)\end{array}$ & $\begin{array}{l}184(108-375) \\
222(119-375)\end{array}$ & $\begin{array}{l}0.544 \\
0.006\end{array}$ & $\begin{array}{l}22.1 \pm 10.7 \\
25.7 \pm 16.0\end{array}$ & $\begin{array}{l}26.7 \pm 13.5 \\
27.8 \pm 17.9\end{array}$ & $\begin{array}{l}0.307 \\
0.418\end{array}$ \\
\hline $\begin{array}{l}\text { Character of chest pain } \\
\text { Pressure, tightness, } \\
\text { Pleuritic } \\
\text { Positional } \\
\text { Unrelated to efor }\end{array}$ & $\begin{array}{l}328(174-448) \\
114(82-219) \\
120(92-232) \\
123(89-278)\end{array}$ & $\begin{array}{l}368(218-450) \\
195(101-321) \\
185(115-280) \\
185(102-324)\end{array}$ & $\begin{array}{l}0.779 \\
0.003 \\
0.040 \\
0.075\end{array}$ & $\begin{array}{l}28.8 \pm 14.6 \\
24.5 \pm 16.2 \\
26.1 \pm 18.6 \\
23.2 \pm 13.3\end{array}$ & $\begin{array}{l}27.2 \pm 11.0 \\
30.2 \pm 21.1 \\
26.3 \pm 17.9 \\
25.8 \pm 15.8\end{array}$ & $\begin{array}{l}0.662 \\
0.106 \\
0.975 \\
0.304\end{array}$ \\
\hline $\begin{array}{l}\text { Pre-diagnosis } \\
\text { NSTEMI } \\
\text { Musculoskletal pain } \\
\text { Pneumothorax } \\
\text { Pneumonia }\end{array}$ & $\begin{array}{c}133(92-281) \\
126(88-265) \\
123(86-274) \\
222(121-345)\end{array}$ & $\begin{array}{l}215(117-363) \\
196(111-309) \\
225(120-311) \\
242(133-403)\end{array}$ & $\begin{array}{l}0.011 \\
0.016 \\
0.083 \\
0.459\end{array}$ & $\begin{array}{l}25.2 \pm 15.4 \\
23.5 \pm 14.4 \\
27.1 \pm 19.9 \\
29.6 \pm 18.7\end{array}$ & $\begin{array}{l}26.5 \pm 15.8 \\
25.7 \pm 16.1 \\
38.7 \pm 30.0 \\
34.4 \pm 15.5\end{array}$ & $\begin{array}{l}0.559 \\
0.358 \\
0.161 \\
0.307\end{array}$ \\
\hline $\begin{array}{l}\text { Imagining methods } \\
\text { ECG } \\
\text { X-ray } \\
\text { CT }\end{array}$ & $\begin{array}{c}133(91-274) \\
130(92-269) \\
155(103-444)\end{array}$ & $\begin{array}{l}215(117-375) \\
225(120-372) \\
357(215-490)\end{array}$ & $\begin{array}{l}0.006 \\
0.002 \\
0.082\end{array}$ & $\begin{array}{l}24.6 \pm 14.8 \\
26.0 \pm 16.3 \\
51.3 \pm 22.6\end{array}$ & $\begin{array}{l}26.7 \pm 15.8 \\
27.8 \pm 17.5 \\
46.4 \pm 21.3\end{array}$ & $\begin{array}{l}0.337 \\
0.485 \\
0.529\end{array}$ \\
\hline $\begin{array}{l}\text { Diagnosis } \\
\text { NSTEMI } \\
\text { Musculoskletal pain }\end{array}$ & $\begin{array}{c}328(214-438) \\
110(81-222)\end{array}$ & $\begin{array}{c}362(223-410) \\
182(96-275)\end{array}$ & $\begin{array}{l}0.855 \\
0.015\end{array}$ & $\begin{array}{l}28.1 \pm 14.8 \\
20.4 \pm 10.7\end{array}$ & $\begin{array}{l}29.9 \pm 14.3 \\
21.5 \pm 11.0\end{array}$ & $\begin{array}{l}0.682 \\
0.576\end{array}$ \\
\hline $\begin{array}{l}\text { Hospitalisation of patient } \\
\text { Discharged } \\
\text { Hospitalise }\end{array}$ & $\begin{array}{c}110(82-211) \\
279(135-413)\end{array}$ & $\begin{array}{l}185(102-313) \\
280(134-443)\end{array}$ & $\begin{array}{c}<0.001 \\
0.721\end{array}$ & $\begin{array}{l}21.4 \pm 12.3 \\
32.9 \pm 17.9\end{array}$ & $\begin{array}{l}24.3 \pm 13.2 \\
36.0 \pm 22.9\end{array}$ & $\begin{array}{l}0.171 \\
0.557\end{array}$ \\
\hline All patients & $133(91-279)$ & $215(118-372)$ & 0.006 & $25.2 \pm 15.3$ & $27.7 \pm 17.3$ & 0.269 \\
\hline
\end{tabular}

In addition, in this study, POCUS did not affect the rate of discharge or hospitalisation, whereas the discharged patients in POCUS group significantly had shorter LOS in the ED [POCUS group: 110 (82-211); control group: 185 (102-313) minutes, $p<0.001]$. The authors believe that this result will decrease the density of the ED and improve the quality of care in clinics, such as our clinic, with a high number of ED visits.

The limitations of this study are: it is a single-center study design used for this trial, and one physician performed all the sonographic examinations; therefore, the results might not be applicable to other EDs or physicians performing POCUS. Patients could not be consecutively enrolled when the investigator for POCUS was not present in the ED, and this might have introduced bias. Involving several physicians performing sonographic examinations would have been preferable, but this was not possible because there were no other emergency physicians with ultrasonography qualification when the study began. Another limitation of this study was that no attempt to ensure the accuracy of the ultrasound-aided decision-making with regard to the final diagnosis, and no blinded evaluation of the images to ensure accuracy of the image interpretation.

\section{CONCLUSION}

POCUS is a reproducible, irradiated, practical imaging method performed by ED physicians and successfully detects pathological findings and helps in the diagnostic process by narrowing the differential diagnosis range and by reducing the LOS in the ED. Crowded ED may improve the delivered quality of patient care. However, cost reduction was not seen. The results obtained should be supported with additional studies because there is no previous study on CP.

\section{ETHICAL APPROVAL:}

The study protocol was approved by the local Ethics Committee [IRB No:16214662/050.01.04/74].

\section{PATIENTS' CONSENT:}

Informed consents were obtained from all participants.

\section{CONFLICT OF INTEREST:}

Authors declared no conflict of interest.

\section{AUTHORS' CONTRIBUTION:}

NGG: Led and conceived the project, and authored the manuscript and statistics.

YY: Data collection, compiling and discussion.

MY: Contributed to design articles, collected and analysed data.

MA: Contributed to collect and analyse data.

STG: Collected and analysed data, literature review and discussion.

BE: Helped perform the analyses with constructive discussions.

\section{REFERENCES}

1. Hamm CW, Goldmann BU, Heeschen C, Kreymann G, Berger J, Meinertz T. Emergency room triage of patients with acute chest pain by means of rapid testing for cardiac troponin $T$ or troponin I. N Engl I Med 1997; 337(23): 1648-53. doi: 10.1056/NEJM199712043372302.

2. Solinas L, Raucci R, Terrazzino S, Moscariello F, Pertoldi F, Vajto $S$, et al. Prevalence, clinical characteristics, resource utilization and outcome of patients with acute chest pain in the emergency department. A multicenter, prospective, observational study in North-Eastern Italy. Ital Hear J 2003; 4(5):318-24.

3. Diercks DB, Hollander JE. Acute coronary syndromes. In: Judith E. Tintinalli O, John Ma, Donald Yealy, Garth D. Meckler J. Stephan Stapczynski, David M. Cline SHT, Ed. Tintinalli's emergency medicine: A comprehensive study guide. 9th edition. New York: McGraw-Hill Education 2019; p.334-52.

4. Mahler SA. Chest Pain. In: Judith E. Tintinalli, O. John Ma, Donald Yealy, Garth D. Meckler, J. Stephan Stapczynski, David M. Cline SHT, Ed. Tintinalli's emergency medicine a 
comprehensive study guide. 9th edition. New York: McGrawHill Education 2019; p.329-34.

5. Kontos MC, Diercks DB, Kirk JD. Emergency department and office-based evaluation of patients with chest pain. In: Mayo clinic proceedings. Elsevier Ltd 2010; 85(3):284-99. doi: 10.4065/mcp.2009.0560.

6. Niska R, Bhuiya F, Xu J. National hospital ambulatory medical care survey: 2007 emergency department summary. Natl Health Stat Report 2010; 26(26):1-31.

7. Ultrasound guidelines: Emergency, point-of-care and clinical ultrasound guidelines in medicine. Vol. 69, Annals of Emergency Medicine. Mosby Inc.; 2017. p. e27-54.

8. Laursen CB, Sloth E, Lassen AT, Christensen R de P, Lambrechtsen J, Madsen $\mathrm{PH}$, et al. Point-of-care ultrasonography in patients admitted with respiratory symptoms: A single-blind, randomised controlled trial. Lancet Respir Med 2014; 2(8):638-46. doi: 10.1016/ S2213-2600(14)70135-3.

9. Ray $\mathrm{P}$, Birolleau S, Lefort $\mathrm{Y}$, Becquemin $\mathrm{MH}$, Beigelman $\mathrm{C}$, Isnard $R$, et al. Acute respiratory failure in the elderly: Etiology, emergency diagnosis and prognosis. Crit Care 2006; 10(3):10(3):R82. doi: 10.1186/cc4926.

10. Moore CL, Copel JA. Point-of-care ultrasonography. N Eng J Med 2011; 364(8):749-57. doi: 10.1056/NEJMra0909487.

11. Kröger K, Küpper-Nybelen J, Moerchel C, Moysidis T, Kienitz C, Schubert I. Prevalence and economic burden of pulmonary embolism in Germany. Vasc Med 2012; 17(5): 303-9. doi: $10.1177 / 1358863 \times 12449363$.

12. Robert G. Newcombe DGA. In: Altman D, Machin D, Bryant T GM, Ed. Statistics with Confidence: Confidence Intervals and Statistical Guidelines. 2nd Edition. London: Wiley; 2000. p. 45-7.

13. Buhumaid RE, St-Cyr Bourque J, Shokoohi H, Ma IWY, Longacre M, Liteplo AS. Integrating point-of-care ultrasound in the ED evaluation of patients presenting with chest pain and shortness of breath. Am J Emerg Med 2019; 37(2):298-303. doi: 10.1016/j.ajem.2018.10.059

14. Lamsam L, Gharahbaghian L, Lobo V. Point-of-care ultra- sonography for detecting the etiology of unexplained acute respiratory and chest complaints in the emergency department: A prospective analysis. Cureus 2018; 10(8): e3218. doi: 10.7759/cureus.3218.

15. Carubbi C, Masselli E, Pozzi G, Mattioli M, Martini S, Goldoni $M$, et al. Combination of Platelet expression of PKCepsilon and cardiac troponin-I for early diagnosis of chest pain patients in the emergency department. Sci Rep 2019; 9(1):2125. doi: 10.1038/s41598-019-38624-5.

16. Yates J, Royse CF, Royse C, Royse AG, Canty DJ. Focused cardiac ultrasound is feasible in the general practice setting and alters diagnosis and management of cardiac disease. Echo Res Pract 2016; 3(3):63-9. doi: 10.1530/ ERP-16-0026.

17. Ahn JH, Jeon J, Toh HC, Noble VE, Kim JS, Kim YS, et al. SEARCH 8Es: A novel point of care ultrasound protocol for patients with chest pain, dyspnea or symptomatic hypotension in the emergency department. PLoS One 2017; 12(3):e0174581. doi: 10.1371/journal.pone. 0174581.

18. Elikashvili I, Tay ET, Tsung JW. The effect of point-of-care ultrasonography on emergency department length of stay and computed tomography utilization in children with suspected appendicitis. Acad Emerg Med 2014; 21(2): 163-70. doi: 10.1111/acem.12319.

19. Lin MJ, Neuman M, Rempell R, Monuteaux M, Levy J. Point-of-Care Ultrasound is Associated With Decreased Length of Stay in Children Presenting to the Emergency Department With Soft Tissue Infection. J Emerg Med 2018; 54(1): 96-101. doi: 10.1016/j.jemermed.2017. 09.017.

20. Park YH, Jung RB, Lee YG, Hong CK, Ahn J-H, Shin TY, et al. Does the use of bedside ultrasonography reduce emergency department length of stay for patients with renal colic? a pilot study. Clin Exp Emerg Med 2016; 3(4):197-203. doi: 10.15441/ceem.15.109

21. Wilson S. Point-of-care ultrasound versus radiology department pelvic ultrasound on emergency department length of stay. World J Emerg Med 2016; 7(3):178. doi: 10.5847/wjem.j.1920-8642.2016.03.003. 